\title{
A Highly Selective Fluorescent Probe for Hypochlorous Acid in Living Cells Based on a Naphthalene Derivative
}

\author{
Jingguo Sun, ${ }^{1}$ Junhong Xu, ${ }^{2}$ Qiujuan Ma $\mathbb{D}^{1},{ }^{1}$ Guojiang Mao $\mathbb{D},{ }^{3}$ Nannan Zhu, ${ }^{1}$ Meiju Tian, \\ Linke Li, ${ }^{1}$ and Shuzhen Liu ${ }^{1}$ \\ ${ }^{1}$ School of Pharmacy, Henan University of Chinese Medicine, Zhengzhou 450046, China \\ ${ }^{2}$ Department of Dynamical Engineering, North China University of Water Resources and Electric Power, \\ Zhengzhou 450011, China \\ ${ }^{3}$ Henan Key Laboratory of Organic Functional Molecule and Drug Innovation, \\ Collaborative Innovation Center of Henan Province for Green Manufacturing of Fine Chemicals, \\ Key Laboratory of Green Chemical Media and Reactions, Ministry of Education, School of Chemistry and Chemical Engineering, \\ Henan Normal University, Xinxiang 453007, China
}

Correspondence should be addressed to Qiujuan Ma; maqiujuan104@126.com and Guojiang Mao; maoguojiang@htu.edu.cn Received 1 August 2021; Accepted 2 December 2021; Published 14 February 2022

Academic Editor: María José Ruiz Ángel

Copyright (C) 2022 Jingguo Sun et al. This is an open access article distributed under the Creative Commons Attribution License, which permits unrestricted use, distribution, and reproduction in any medium, provided the original work is properly cited.

Hypochlorous acid $(\mathrm{HOCl})$ was crucial for maintaining the homeostasis in cells and plays vital roles in many physiological and pathological processes. In this work, a highly selective fluorescent probe for hypochlorous acid in living cells was constructed and prepared based on a naphthalene derivative. A naphthalene derivative was utilized as the fluorescent group, and $N, N$-dimethylthiocarbamate was applied as the selective recognition site for $\mathrm{HOCl}$. Before adding $\mathrm{HOCl}$, the fluorescent probe exhibited weak fluorescence. Upon adding $\mathrm{HOCl}$, the fluorescent probe displayed remarkable fluorescence enhancement. The fluorescence intensity at $502 \mathrm{~nm}$ showed a linear response to the concentration of $\mathrm{HOCl}$ from $3.0 \times 10^{-7}$ to $1.0 \times 10^{-5} \mathrm{~mol} \cdot \mathrm{L}^{-1}$. The detection limit was estimated to be $1.5 \times 10^{-7} \mathrm{~mol} \cdot \mathrm{L}^{-1}$ for $\mathrm{HOCl}$. The fluorescent probe showed fast response and outstanding selectivity toward HOCl. It owned good biocompatibility and had also been successfully applied in the confocal imaging of exogenous and endogenous $\mathrm{HOCl}$ in living cells.

\section{Introduction}

Hypochlorous acid $(\mathrm{HOCl})$, as an important reactive oxygen species (ROS), played a vital role in various physiological and pathological processes [1, 2]. Among various ROS, hypochlorous acid $(\mathrm{HOCl})$, which was produced by $\mathrm{H}_{2} \mathrm{O}_{2}$ and $\mathrm{Cl}^{-}$through myeloperoxidase (MPO) [3, 4], was an effective antibacterial agent in the process of human immune defense [5]. Despite its protective effect on immune systems and human health, irregular levels of $\mathrm{HOCl}$ were closely associated with many serious diseases, such as osteoarthritis [6], atherosclerosis [7], kidney disease [8], and neurodegeneration [9]. Thus, monitoring the cellular $\mathrm{HOCl}$ concentration was very important for biological research and clinical diagnosis.
Many analytical methods had been utilized to detect $\mathrm{HOCl}$, such as electrochemical analysis [10], mass spectrometry [11], high-performance liquid chromatography [12], ultraviolet-visible spectrophotometry [13], chemiluminescence detection [14], and fluorometry [15]. In these methods, fluorescent assay for $\mathrm{HOCl}$ possessed the prominent characteristics of rapidity, high sensitivity, and selectivity, noninvasiveness, and real-time determination [16-18]. Therefore, most fluorescent probes for detecting $\mathrm{HOCl}$ had been reported. The design strategy of most $\mathrm{HOCl}$ fluorescent probes was based on the specific reaction between the recognition group and $\mathrm{HOCl}$, thereby producing a strong fluorescent product. These $\mathrm{HOCl}$ recognition groups included $p$-methoxyphenol [19], $p$-aminophenyl ether $[20,21]$, thioether [22-24], thioester [25, 26], hydrazide 
[27-29], rhodamine hydroxamic acid [30], selenide [31, 32], unsaturated $\mathrm{C}=\mathrm{C}[33-35]$, oxime $[36,37]$, thiocarbamate $[38,39]$, and others [40]. These specific reactions could effectively distinguish $\mathrm{HOCl}$ from other ROS. However, some of these $\mathrm{HOCl}$ fluorescent probes had some limitations for the detection of real samples such as relatively slow response time $[27,40]$ and comparatively low sensitivity $[31,36]$. Thus, it was still desirable that a new $\mathrm{HOCl}$ fluorescent probe possessed rapid response time and high sensitivity.

Naphthalene derivatives owing a donor- $\pi$-acceptor (D$\pi$-A) structure had been extensively applied to construct fluorescent probes due to their many advantages such as superior light stability, better chemical stability, and high fluorescence quantum yield. In the past few years, the naphthalene-based fluorescent probes for various substances had been reported including thiophenols [41], HNO [42], $\mathrm{H}_{2} \mathrm{O}_{2}$ [43], cysteine [44], hydrogen polysulfides [45], $\mathrm{ONOO}^{-}$[46], and $\mathrm{F}^{-}$[47]. In this study, a fluorescent probe 1 for $\mathrm{HOCl}$ was designed and prepared based on a naphthalene derivative (Scheme 1). N, N-Dimethylthiocarbamate was applied as a sensing unit for $\mathrm{HOCl}$. Studied results demonstrated the probe possessed excellent sensitivity, a wide $\mathrm{pH}$ range, superior selectivity, and fast response time. Furthermore, the probe displayed almost no cell cytotoxicity and had been effectively utilized in the confocal imaging of exogenous and endogenous $\mathrm{HOCl}$ in living cells.

\section{Experimental}

2.1. Materials and Instruments. Dimethylaminothioformyl chloride and $\mathrm{N}, \mathrm{N}$-diisopropylethylamine were bought from Tianjin Heowns Biochemical Technology Company. $p$-Toluenesulfonic acid monohydrate was purchased from China National Pharmaceutical Group Chemical Reagent Company. 6-Hydroxy-2-naphthaldehyde and 2-aminothiophenol were obtained from Saen Chemical Technology (Shanghai) Company. Sodium hypochlorite was purchased from Tianjin Fuyu Fine Chemical Company. Hydrogen peroxide $\left(\mathrm{H}_{2} \mathrm{O}_{2}\right)$ and tertbutyl hydroperoxide (TBHP) were obtained from $30 \%$ to $70 \%$ aqueous solutions, respectively. Hydroxyl radical $(\cdot \mathrm{OH})$ and tert-butoxy radical $\left(\mathrm{O}^{t} \mathrm{Bu}\right)$ were produced by reaction of $1 \mathrm{mM} \mathrm{Fe}^{2+}$ with $200 \mu \mathrm{M} \mathrm{H}_{2} \mathrm{O}_{2}$ or $200 \mu \mathrm{M}$ TBHP, respectively. Superoxide $\left(\mathrm{O}_{2}{ }^{-}\right)$was generated from potassium superoxide $\left(\mathrm{KO}_{2}\right)$ solid diluted in dimethyl sulfoxide (DMSO). Singlet oxygen $\left({ }^{1} \mathrm{O}_{2}\right)$ was yielded by the reaction of $1 \mathrm{mM} \mathrm{ClO}^{-}$with $200 \mu \mathrm{M} \mathrm{H}_{2} \mathrm{O}_{2}$. Peroxynitrite $\left(\mathrm{ONOO}^{-}\right)$solution was prepared by the reaction of $\mathrm{H}_{2} \mathrm{O}_{2}$ and $\mathrm{NaNO}_{2}$, and its concentration was assessed from absorption at $\lambda=302 \mathrm{~nm}$ $\left(\varepsilon=1670 \mathrm{~L} \cdot \mathrm{mol}^{-1} \cdot \mathrm{cm}^{-1}\right)[40]$. Unless otherwise specified, all other chemical reagents were of analytical purity, obtained from commercial suppliers and used without further purification. Silica gel used for thin layer chromatography is 60 F254, and the silica gel used in column chromatography is 200-300 mesh, both of which were obtained from the Qingdao Ocean Chemicals (Qingdao, China). Water was purified by the SZ-93 automatic double pure water distiller (Shanghai Yarong Biochemical Instrument Factory) and used for the preparation of all aqueous solutions. $\mathrm{HOCl}$ was standardized at pH $12\left(\varepsilon_{292 \mathrm{~nm}}=350 \mathrm{~L} \cdot \mathrm{mol}^{-1} \cdot \mathrm{cm}^{-1}\right)$ [40].

The NMR spectrum was measured with a Bruker DRX500 NMR spectrometer using tetramethylsilane (TMS) as the internal standard. The mass spectrum was obtained on an Agilent 6420 triple quadrupole LC/MS high resolution mass spectrometer. Fluorescence tests were performed on a Hitachi F-7000 fluorescence spectrophotometer equipped with a $1 \mathrm{~cm}$ quartz absorption cell (Tokyo, Japan). The UVvisible absorption spectrum was measured by an Evolution 260 Bio UV-Vis spectrophotometer with a $1 \mathrm{~cm}$ quartz absorption cell. The $\mathrm{pH}$ values were measured by the Mettler Toledo $\mathrm{pH}$ meter. Fluorescence imaging of living cells was recorded by an Olympus FV-1200 single photon laser confocal microscope. Data processing was mainly obtained in SigmaPlot software. The data obtained by fluorescence spectrophotometry and UV-visible spectrophotometry were measured in $0.01 \mathrm{~mol} \cdot \mathrm{L}^{-1}$ PBS buffer (DMF/Water $=2: 8$, $\mathrm{V} / \mathrm{V}, \mathrm{pH}=7.40$ ). Except the fluorescence data recorded by time scanning, all other fluorescence and absorption data were measured at $3 \mathrm{~min}$ after adding $\mathrm{HOCl}$ at room temperature.

2.2. Syntheses. The synthetic route for fluorescence probe 1 is illustrated in Scheme 1.

2.2.1. Synthesis of Compound 2. 2-Aminothiophenol $(0.69 \mathrm{~g}$, $5.5 \mathrm{mmol}$ ) was dissolved in $5 \mathrm{~mL}$ ethanol and then added dropwisely to a $35 \mathrm{~mL}$ ethanol solution containing 6-hydroxy2-naphthaldehyde $(0.86 \mathrm{~g}, 5 \mathrm{mmol})$ and $p$-toluenesulfonic acid monohydrate $(1.90 \mathrm{~g}, 10 \mathrm{mmol})$ at room temperature. Then, the reaction mixture was heated to reflux for 12 hours, and the solvent was evaporated under reduced pressure to obtain a crude product. The crude product was subjected to column chromatography with petroleum ether/ethyl acetate (4:1, V/V) as the eluent to obtain compound $2(1.05 \mathrm{~g}, 76 \%)$ as a yellow solid. ${ }^{1} \mathrm{H}$ NMR $\left(500 \mathrm{MHz}, \mathrm{DMSO}-d_{6}\right), \delta(\mathrm{ppm}): 10.11(1 \mathrm{H}, \mathrm{s})$, $8.54(1 \mathrm{H}, \mathrm{s}), 8.14(1 \mathrm{H}, d, J=7.9 \mathrm{~Hz}), 8.08(1 \mathrm{H}, \mathrm{dd}, J=8.6 \mathrm{~Hz}$, $J=1.6 \mathrm{~Hz}), 8.05(1 \mathrm{H}, d, J=8.0 \mathrm{~Hz}), 8.00(1 \mathrm{H}, d, J=8.8 \mathrm{~Hz}), 7.84$ $(1 \mathrm{H}, d, J=8.6 \mathrm{~Hz}), 7.55-7.52(1 \mathrm{H}, \mathrm{m}), 7.46-7.43(1 \mathrm{H}, \mathrm{m})$, $7.20-7.16(2 \mathrm{H}, \mathrm{m}) .{ }^{13} \mathrm{C}$ NMR $\left(125 \mathrm{MHz}, \mathrm{DMSO}-d_{6}\right), \delta(\mathrm{ppm})$ : $168.19,157.63,154.18,136.63,134.82,131.20,127.83,127.78$, $127.74,127.57,127.06,125.75,124.65,123.08,122.73,120.26$, 109.40. MS (ESI) $\mathrm{m} / \mathrm{z}: 278.0638(\mathrm{M}+\mathrm{H})^{+}$.

2.2.2. Synthesis of Probe 1. Under nitrogen flow, compound $2(0.28 \mathrm{~g}, 1 \mathrm{mmol})$ was dissolved in $20 \mathrm{~mL}$ mixture solvent (anhydrous $\mathrm{CH}_{2} \mathrm{Cl}_{2}$ : anhydrous $\mathrm{DMF}=4: 1, \mathrm{~V} / \mathrm{V}$ ). Then, $0.45 \mathrm{~mL} \mathrm{~N}, \mathrm{~N}$-diisopropylethylamine (DIPEA) was added to the above solution. Next, $N, N$-dimethylaminothioformyl chloride $(0.61 \mathrm{~g}, 5 \mathrm{mmol})$ was slowly added to the above mixed solution in batches. The reaction mixture was stirred at room temperature. Then, the solvent was evaporated under reduced pressure, and the crude product was purified by column chromatography using dichloromethane/methanol $(50: 1, \mathrm{~V} / \mathrm{V})$ as the eluent to obtain probe $1(0.25 \mathrm{~g}, 70 \%)$. ${ }^{1} \mathrm{H}$ NMR $\left(500 \mathrm{MHz}, \mathrm{CDCl}_{3}\right), \delta(\mathrm{ppm}): 8.58(1 \mathrm{H}, \mathrm{s}), 8.21(1 \mathrm{H}$, 
$\mathrm{dd}, J=8.6 \mathrm{~Hz}, 1.1 \mathrm{~Hz}), 8.11(1 \mathrm{H}, d, J=8.1 \mathrm{~Hz}), 7.97(1 \mathrm{H}, d$, $J=8.8 \mathrm{~Hz}$ ), $7.93-7.89$ (2H, m), 7.53-7.49 (2H, m), 7.41-7.38 $(1 \mathrm{H}, \mathrm{m}), 7.31(1 \mathrm{H}, \mathrm{dd}, J=8.8 \mathrm{~Hz}, 2.1 \mathrm{~Hz}), 3.48(3 \mathrm{H}, \mathrm{s}), 3.40$ $(3 \mathrm{H}, \mathrm{s}) .{ }^{13} \mathrm{C}$ NMR $\left(125 \mathrm{MHz}, \mathrm{CDCl}_{3}\right), \delta$ (ppm): 187.52, $168.05,153.76,152.89,135.03,134.86,131.24,130.64,129.91$, $128.66,127.58,126.54,125.40,125.07,123.72,123.12,121.66$, 119.68, 43.32, 38.85. MS (ESI) $\mathrm{m} / \mathrm{z}: 365.0790(\mathrm{M}+\mathrm{H})^{+}$, $387.0610(\mathrm{M}+\mathrm{Na})^{+}$.

2.3. Cytotoxicity Assay. To assess the cytotoxicity of the probe, 3-(4, 5-dimethylthiazole-2)-2, 5-diphenyltetrazolium bromide (MTT) assay was carried out. First, PC-12 cells were hatched in 1640 medium supplemented with $10 \%$ fetal bovine serum, 100 units $\mathrm{mL}^{-1}$ penicillin, and $100 \mu \mathrm{g} \mathrm{mL}^{-1}$ streptomycin. The PC12 cells in the logarithmic growth phase were planted in a 96well plate with about $1 \times 10^{4}$ cells in each well, and the total volume of each well was $100 \mu \mathrm{L}$. The cells were cultured in an incubator containing $5 \% \mathrm{CO}_{2}$ for $24 \mathrm{~h}$. The medium was deserted and cleaned with Dulbecco's phosphate buffered saline (DPBS) for three times. Next, the fresh media containing probe $1(0,2,4,8$, and $16 \mu \mathrm{M})$ and the purified product of compound 1 with $\mathrm{HOCl}(0,2,4,8$, and $16 \mu \mathrm{M})$ were introduced into the wells, respectively, and incubated for $24 \mathrm{~h}$. Subsequently, $10 \mu \mathrm{L}$ MTT ( $5 \mathrm{mg} \cdot \mathrm{mL}^{-1}$ ) was added to per well, and the PC-12 cells were fostered for $4 \mathrm{~h}$ allowing the formation of formazan. Finally, the above loading media was deserted, and $150 \mu \mathrm{L}$ DMSO was added to the wells. The 96-well plates were shaken for $10 \mathrm{~min}$, and the absorbance at $490 \mathrm{~nm}$ was measured utilizing a microplate reader (Synergy 2, BioTek Instruments Inc.). The survival rate was assessed referring to $A$ / $A_{0} \times 100 \%$ ( $A$ and $A_{0}$ denote the absorbance of the experimental group and control group, respectively). Similarly, MTT assay of the probe for RAW 264.7 cells was performed.

2.4. Confocal Imaging in Living Cells. The PC-12 cells and RAW 264.7 cells were incubated in laser confocal culture dishes at $37^{\circ} \mathrm{C}$ for $24 \mathrm{~h}$ to allow good cell growth and then cleaned three times with DPBS. In the experiment of imaging exogenous $\mathrm{HOCl}, \mathrm{PC}-12$ cells were cultured in a medium containing $5.0 \mu \mathrm{M}$ fluorescent probe 1 at $37^{\circ} \mathrm{C}$ for $30 \mathrm{~min}$ and then washed with DPBS for three times and imaged. In the control experiment imaging exogenous $\mathrm{HOCl}, \mathrm{PC}-12$ cells were cultured in the medium containing $5.0 \mu \mathrm{M}$ probe for $30 \mathrm{~min}$ at $37^{\circ} \mathrm{C}$, and the supernatant was sucked out. After cleaning with DPBS, the complete culture medium containing $10 \mu \mathrm{M} \mathrm{HOCl}$ was added, incubated for another $30 \mathrm{~min}$, and imaged. The PC12 cells were washed with DPBS for three times for imaging. In the experiment of imaging endogenous $\mathrm{HOCl}$, RAW 264.7 cells were cultured in a medium containing $5.0 \mu \mathrm{M}$ fluorescent probe 1 at $37^{\circ} \mathrm{C}$ for $30 \mathrm{~min}$ and then washed with DPBS for three times and imaged. In the control experiment imaging endogenous $\mathrm{HOCl}$, RAW 264.7 cells were stimulated with PMA $(1.5 \mu \mathrm{g} / \mathrm{mL})$ for $30 \mathrm{~min}$ and then incubated with $5.0 \mu \mathrm{M}$ probe 1 for $30 \mathrm{~min}$ and imaged. Next, RAW 264.7 cells were stimulated with $1.5 \mu \mathrm{g} / \mathrm{mL}$ PMA for $30 \mathrm{~min}$, cultured with $5 \mu \mathrm{g} /$ $\mathrm{mL}$ taurine, incubated with $5.0 \mu \mathrm{M}$ probe 1 for $30 \mathrm{~min}$, and imaged. The fluorescence imaging of cells was acquired on the
Olympus FV1200-MPE single photon confocal inverted microscope with a $40 \times$ objective lens.

\section{Results and Discussion}

3.1. Spectroscopic Analytical Characteristic of Probe 1 for $\mathrm{HOCl}$. In order to investigate the fluorescence recognizing properties of the probe for $\mathrm{HOCl}$, the emission spectra in the absence and presence of $\mathrm{HOCl}$ were recorded in $0.01 \mathrm{~mol} \cdot \mathrm{L}^{-1} \mathrm{PBS}$ buffer $\left(\mathrm{DMF} / \mathrm{H}_{2} \mathrm{O}=2: 8\right.$, $\mathrm{V} / \mathrm{V}, \mathrm{pH}=7.40$ ) (Figure 1). As shown in Figure 1, before adding $\mathrm{HOCl}$, the free probe displayed weak fluorescence at $502 \mathrm{~nm}$ because the internal charge transfer (ICT) process was inhibited. Upon the addition of gradually increased concentration of $\mathrm{HOCl}$, the probe emitted a gradually increased enhancement in fluorescence at $502 \mathrm{~nm}$ because the ICT process was resumed. In the presence of $10 \mu \mathrm{M} \mathrm{HOCl}$, about 25 times fluorescence enhancement at $502 \mathrm{~nm}$ was observed. The above findings established the basis for the determination of $\mathrm{HOCl}$ concentration with probe 1 developed in the present study. We also investigated the absorption spectra of probe 1 in the absence and the presence of $\mathrm{HOCl}$ (Figure S1). As shown in Figure S1, when $\mathrm{HOCl}$ was absent, free probe 1 exhibited a maximum absorption peak at $323 \mathrm{~nm}$. After adding $\mathrm{HOCl}$, a major absorption band at $333 \mathrm{~nm}$ was observed.

3.2. Rule of Operation and the Base of Quantitative Assay. In order to study the linear relationship between the fluorescence intensity of probe 1 and the concentration of $\mathrm{HOCl}$, different concentrations of $\mathrm{HOCl}$ were added to the probe. The excitation wavelength of probe was $350 \mathrm{~nm}$. When the concentration of $\mathrm{HOCl}$ was in the range of $3.0 \times 10^{-7} \mathrm{~mol} \cdot \mathrm{L}^{-1}$ to $1.0 \times 10^{-5} \mathrm{~mol} \cdot \mathrm{L}^{-1}$, the fluorescence intensity of probe had a linear relationship with the concentration of $\mathrm{HOCl}$ (Figure 2). The linear regression equation was $F=63.5503+223.0080 \times 10^{6} \times C(r=0.9988)$, where $F$ denotes the measured fluorescence intensity, $C$ represents the concentration of $\mathrm{HOCl}$, and $r$ is the linear correlation coefficient. The detection limit was calculated by three times standard deviation of blank solution $[48,49]$. The detection limit was found to be $1.5 \times 10^{-7} \mathrm{~mol} \cdot \mathrm{L}^{-1}$ for the fluorescent probe. Compared with the detection limit of $5.86 \times 10^{-7} \mathrm{~mol} \cdot \mathrm{L}^{-1}$ in reference [31] and the detection limit of $5.8 \times 10^{-7} \mathrm{~mol} \cdot \mathrm{L}^{-1}$ in reference [36], the fluorescent probe in this work displayed a higher sensitivity. The investigated findings illustrated that the probe could be applied as a high sensitive fluorescence probe for quantitative determination of $\mathrm{HOCl}$.

3.3. Time-Dependent Response of Probe 1 toward $\mathrm{HOCl}$. We studied the time response of probe for $\mathrm{HOCl}$ by recording the fluorescence intensity of the probe changes with time before and after adding $10 \mu \mathrm{M} \mathrm{HOCl}$ (Figure 3). As shown in Figure 3, in the absence of $\mathrm{HOCl}$, there was no change in the fluorescence intensity of the probe with time. When $\mathrm{HOCl}$ was added, the maximum value reached at 


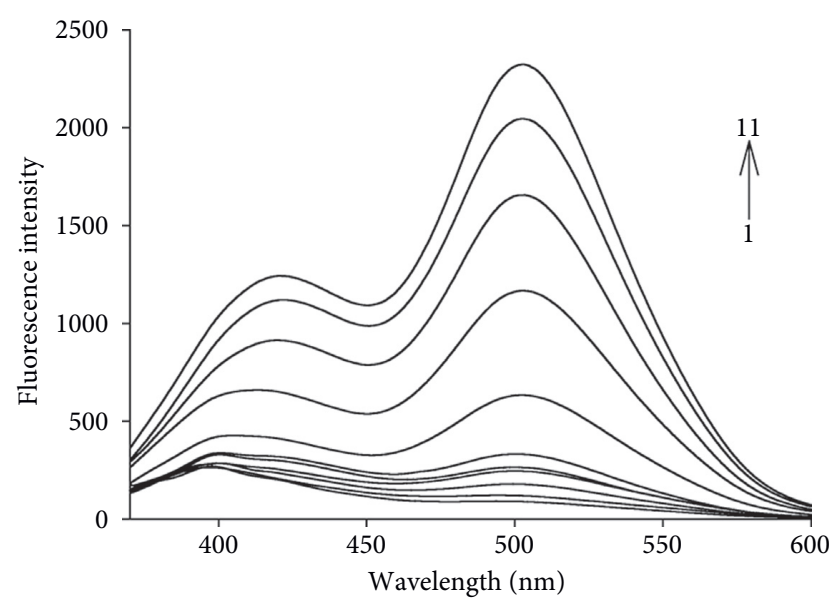

FIGURE 1: Fluorescence spectra of probe 1 after adding various concentrations of $\mathrm{HOCl}: 0,0.30,0.50,0.70,0.90,1.0,3.0,5.0,7.0,9.0,10 \mu \mathrm{M}$ from 1 to $11(\lambda \mathrm{ex}=350 \mathrm{~nm})$.

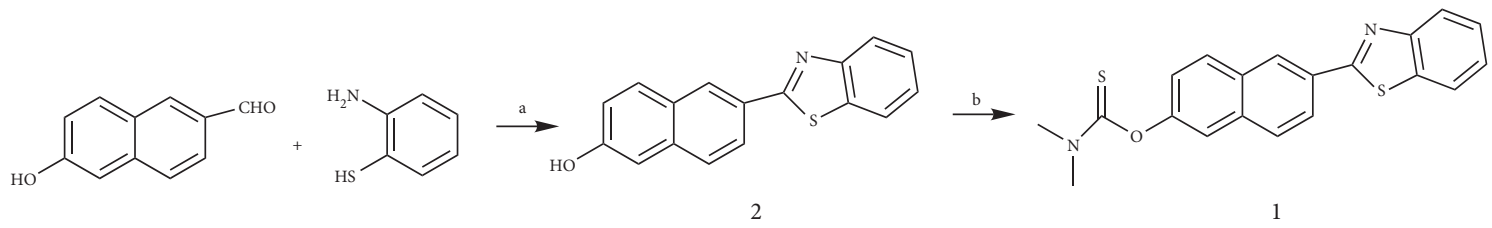

Scheme 1: The prepared procedure of probe 1: (a) ethanol, p-toluenesulfonic acid monohydrate, reflux, 12h 76\%; (b) anhydrous dichloromethane, $\mathrm{N}, \mathrm{N}$-diisopropylethylamine, dimethylaminothioformyl chloride, room temperature, $24 \mathrm{~h} 70 \%$.

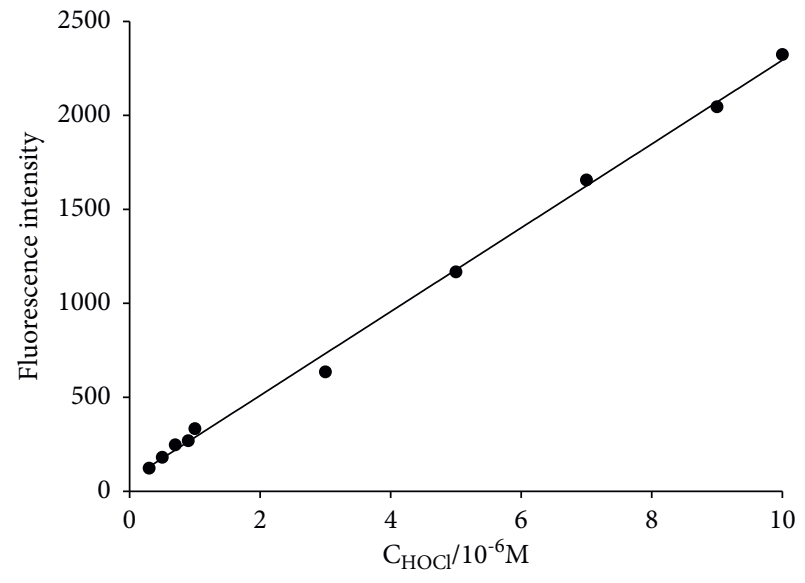

FIGURE 2: Plot of the fluorescence intensity of probe $1(5.0 \mu \mathrm{M})$ as a function of the concentration of $\mathrm{HOCl}$ from 0.30 to $10 \mu \mathrm{M}$ $(\lambda \mathrm{em}=502 \mathrm{~nm})$.

about $3 \mathrm{~min}$, indicating that the probe responded extremely fast. In the present study, an assay time of 3 min was applied as the measurement condition.

3.4. Effect of $p H$. In order to investigate whether the probe had the ability to respond to $\mathrm{HOCl}$ under physiological conditions, the effect of $\mathrm{pH}$ on its fluorescence performance was studied. The changes of probe $1(5 \mu \mathrm{M})$ without and with $\mathrm{HOCl}(10 \mu \mathrm{M})$ at different $\mathrm{pH}$ values

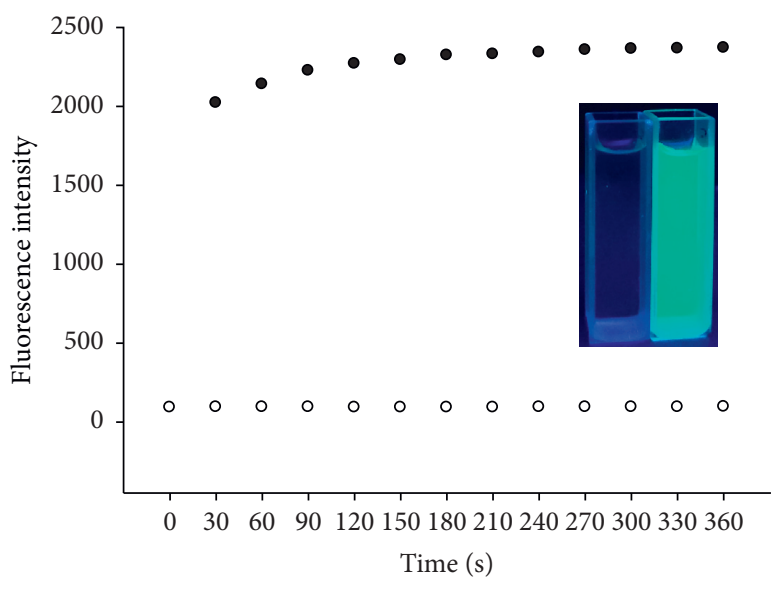

- Compound $1+\mathrm{HOCl}$

- Compound 1

FIgURE 3: Time course of fluorescence intensity of probe $1(5.0 \mu \mathrm{M})$ in the absence (filled circles) and presence of $10 \mu \mathrm{M} \mathrm{HOCl}$ (clear circles). The inset shows the visual fluorescence color of probe 1 $(5.0 \mu \mathrm{M})$ before (left) and after (right) incubation with $10 \mu \mathrm{M} \mathrm{HOCl}$ for $3 \mathrm{~min}$ (UV lamp, $365 \mathrm{~nm}$ ).

were recorded (Figure 4). As shown in Figure 4, the probe exhibited a high sensitivity for $\mathrm{HOCl}$ in the $\mathrm{pH}$ range of 2.00-11.00. The above studied results demonstrated that the probe could work in a larger $\mathrm{pH}$ range and could be applied for $\mathrm{HOCl}$ determination in the biological system. 


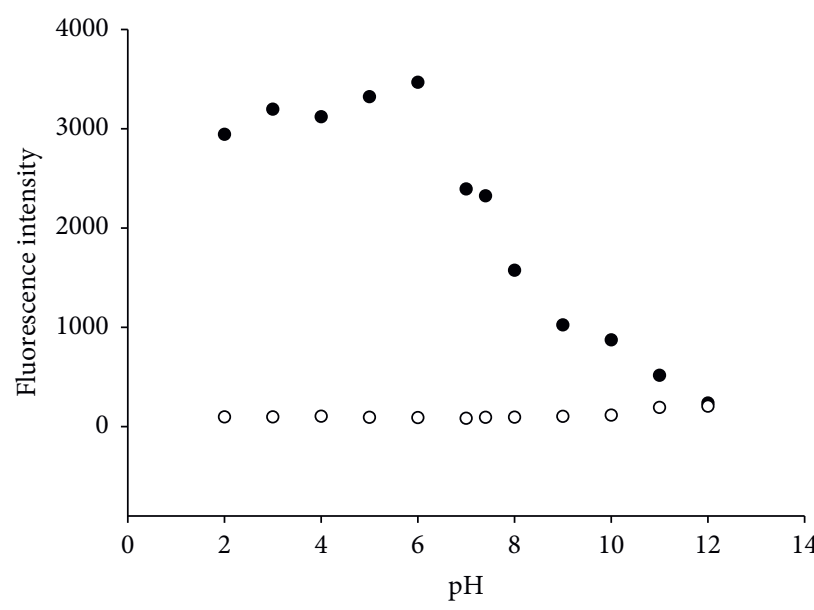

- Compound $1+\mathrm{HOCl}$

o Compound 1

Figure 4: Influence of $\mathrm{pH}$ on fluorescence intensity of $5.0 \mu \mathrm{M}$ probe in the absence (clear circles) and presence of $10 \mu \mathrm{M} \mathrm{HOCl}$ (filled circles).

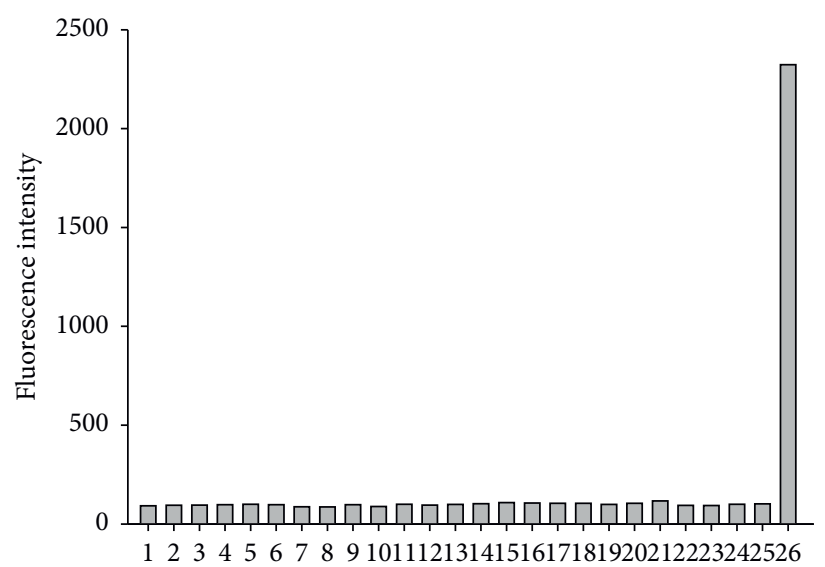

FIGURE 5: Fluorescence response of the probe $(5.0 \mu \mathrm{M})$ toward various analytes in $0.01 \mathrm{~mol} \cdot \mathrm{L}^{-1} \mathrm{PBS}$ buffer $(\mathrm{DMF} / \mathrm{water}=2: 8, \mathrm{~V} / \mathrm{V}$, $\mathrm{pH}=7.40$ ). The fluorescence intensity plotted versus substances: (1) blank; (2) $0.5 \mathrm{mMK}^{+}$; (3) $0.5 \mathrm{mM} \mathrm{Na}^{+}$; (4) $0.5 \mathrm{mM} \mathrm{Ca}^{2+}$; (5) $0.5 \mathrm{mM} \mathrm{Mg}^{2+}$; (6) $0.5 \mathrm{mM} \mathrm{Zn}^{2+}$; (7) $0.5 \mathrm{mM} \mathrm{Fe}^{2+}$; (8) $10 \mu \mathrm{M} \mathrm{Fe}^{3+}$; (9) $0.5 \mathrm{mM} \mathrm{Al}^{3+}$; (10) $0.5 \mathrm{mM} \mathrm{NO}_{2}^{-}$; (11) $0.5 \mathrm{mM} \mathrm{NO}_{3}^{-}$; (12) $0.5 \mathrm{mM} \mathrm{Cu}^{2+}$; (13) $0.5 \mathrm{mM} \mathrm{Pb}^{2+}$; (14) $10 \mu \mathrm{M} \mathrm{Ag}^{+}$; (15) $0.1 \mathrm{mM} \mathrm{Cys;} \mathrm{(16)} 0.1 \mathrm{mM} \mathrm{GSH}$; (17) $0.1 \mathrm{mM} \mathrm{Hcy}$; (18) $0.5 \mathrm{mM} \mathrm{H}_{2} \mathrm{O}_{2}$; (19) $0.5 \mathrm{mM} \mathrm{TBHP}$; (20) $0.5 \mathrm{mM}$ $\mathrm{O}_{2}{ }^{-}$; (21) $10 \mu \mathrm{M}^{1} \mathrm{O}_{2}$; (22) $10 \mu \mathrm{M} \mathrm{OH} ;(23) 10 \mu \mathrm{M} \cdot \mathrm{O}^{t} \mathrm{Bu}$; (24) $0.1 \mathrm{mM}$ ascorbic acid; (25) $10 \mu \mathrm{M} \mathrm{ONOO}^{-}$; (26) $10 \mu \mathrm{M} \mathrm{HOCl}$.

3.5. Selectivity. The selectivity of the fluorescent probe determined its availability in actual samples, so we conducted a selective investigation on probe (Figure 5). As shown in Figure 5, when the $\mathrm{pH}$ was 7.40 , we studied the fluorescence intensity of probe for $\mathrm{HOCl}$ and other related substances including reactive oxygen species (ROS), reactive nitrogen species (RNS), and metal ions. When $10 \mu \mathrm{M} \mathrm{HOCl}$ was added, the fluorescence intensity of the probe increased significantly, and there was no obvious response to other substances. These investigated findings demonstrated that the probe 1 had high selectivity for $\mathrm{HOCl}$.

3.6. Proposed Sensing Mechanism. Referring to previous literature $[38,39,50-52]$, we evaluated that the production of intermediate immonium was first induced by $\mathrm{Cl}^{+}$from the decomposition of $\mathrm{HOCl}$, and the sequent attack of $\mathrm{Cl}^{+}$ resulted in unstable formate ester after the hydrolysis; as a result, compound 2 was yielded through the sequent hydrolysis (Scheme 2). In order to disclose the sensing mechanism of the probe for $\mathrm{HOCl}$, we investigated the reaction mixture of probe 1 with $\mathrm{HOCl}$ by the high resolving mass spectrum (HRMS) (Figure S2). As shown in Figure S2, a novel mass peak at $\mathrm{m} / \mathrm{z} 276.0493$ appeared, which demonstrated the yield of compound 2 (calcd m/z 276.0489 [M$\mathrm{H}]^{-}$). The above investigated results confirmed the proposed response mechanism of the probe toward $\mathrm{HOCl}$ in Scheme 2.

3.7. Cytotoxicity Assays and Confocal Imaging in Living Cells. The cytotoxicity was an important factor to estimate the performance of the probe. MTT assay was applied to 


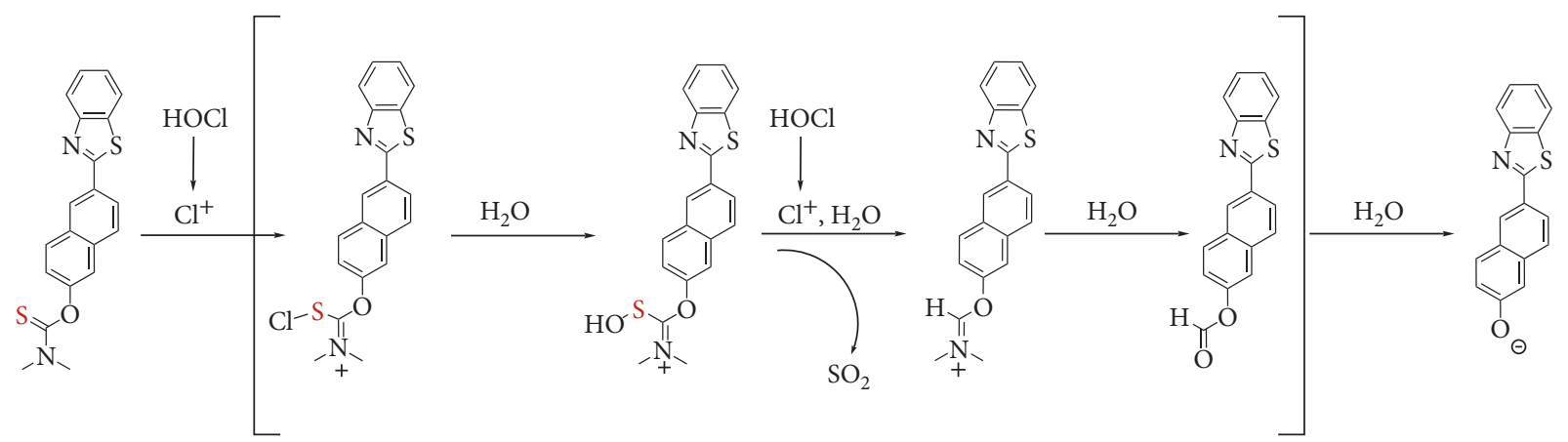

Scheme 2: Proposed reaction mechanism of probe 1 with $\mathrm{HOCl}$.

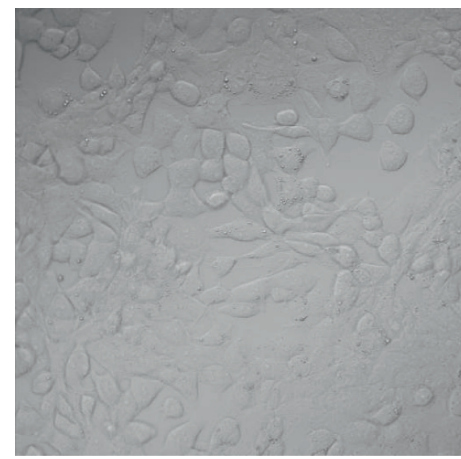

(a)

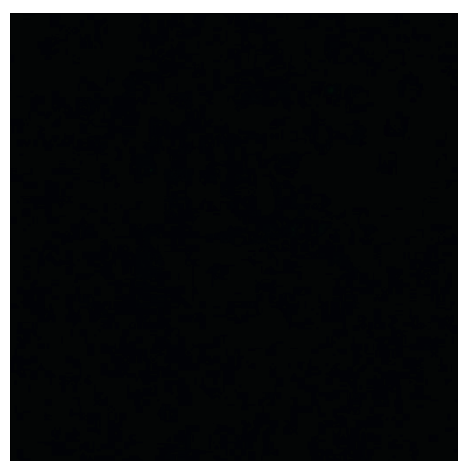

(b)

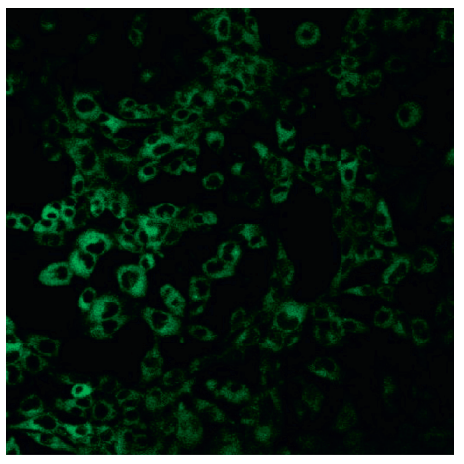

(e)

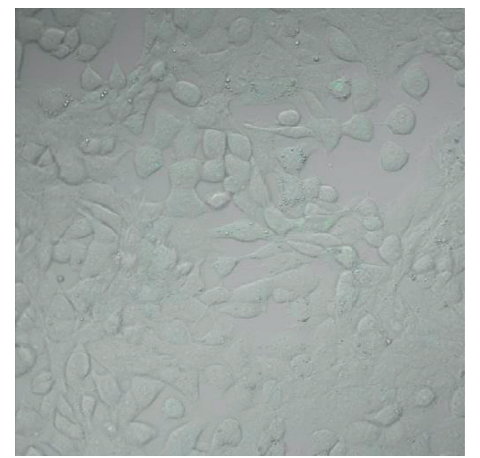

(c)

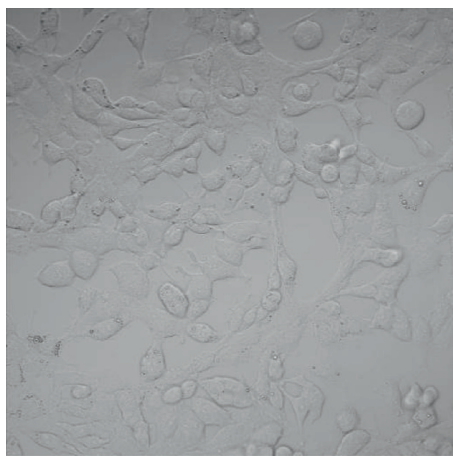

(d)

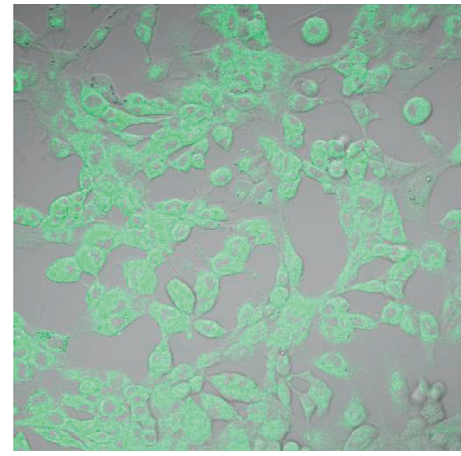

(f)

FIGURE 6: Laser confocal fluorescence imaging of fluorescent probe for HOCl in PC-12: (a) bright field image after incubating PC-12 cells with $5.0 \mu \mathrm{M}$ probe 1 for $30 \mathrm{~min}$; (b) fluorescence image from green channel of image (a); (c) the overlay of (a) and (b); (d) bright field image of PC-12 cells incubated with $5.0 \mu \mathrm{M}$ probe 1 for $30 \mathrm{~min}$ and then incubated with $10 \mu \mathrm{M} \mathrm{HOCl}$ for $30 \mathrm{~min}$; (e) fluorescence image from green channel of image (d); (f) the overlay of (d) and (e). 


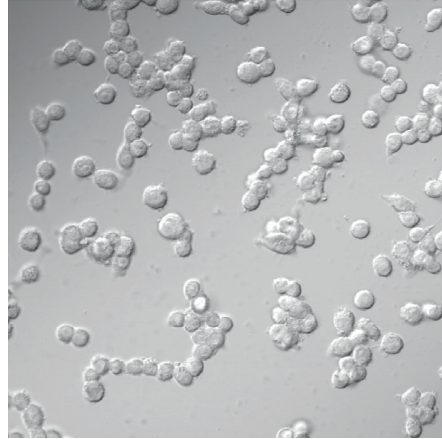

(a)

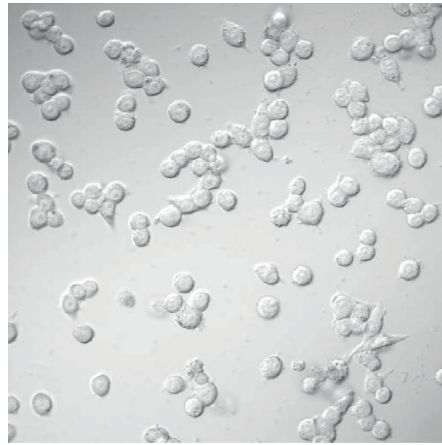

(d)

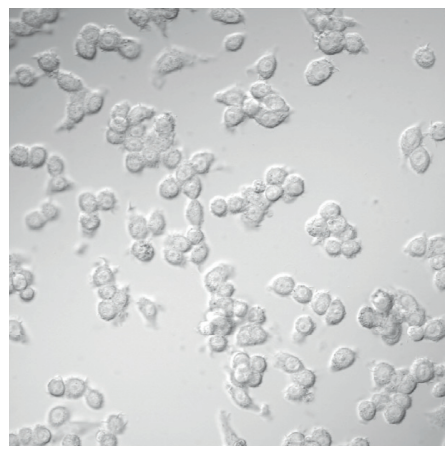

(g)

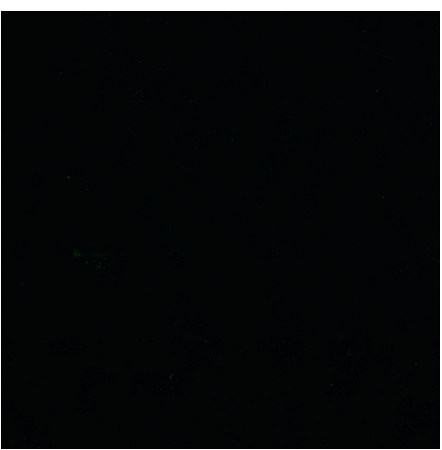

(b)

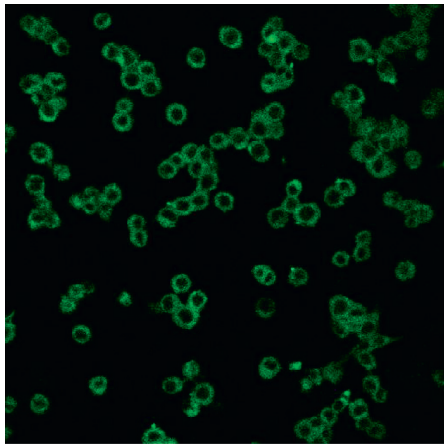

(e)

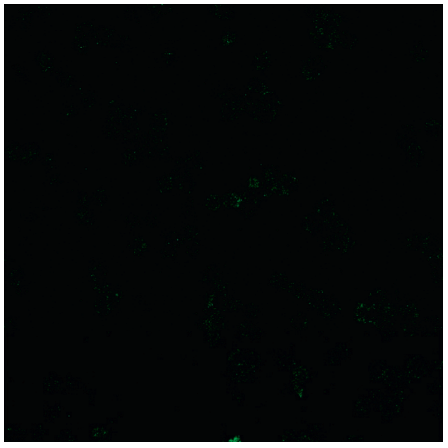

(h)

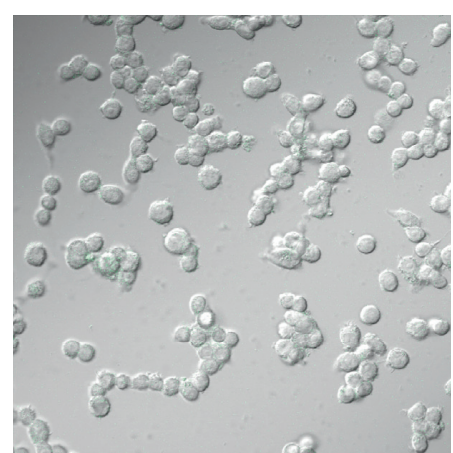

(c)

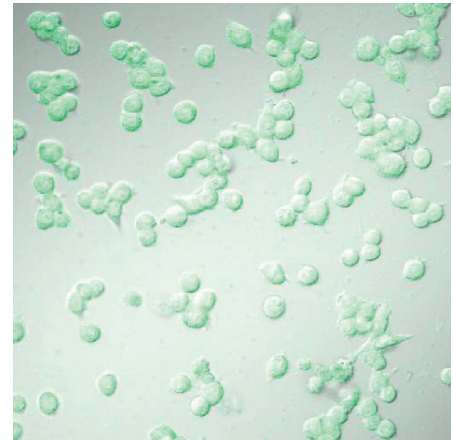

(f)

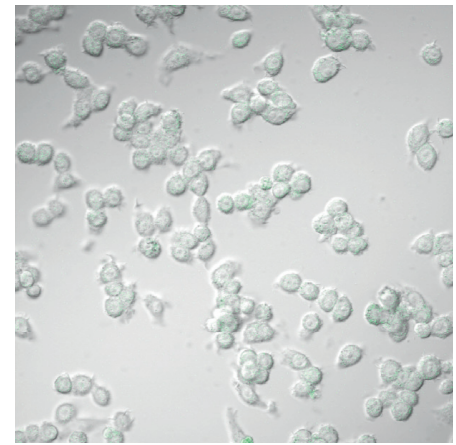

(i)

FIGURE 7: Laser confocal fluorescence imaging of fluorescent probe for $\mathrm{HOCl}$ in RAW 264.7 cells: (a) bright field image after incubating RAW 264.7 cells with $5.0 \mu \mathrm{M}$ probe 1 for $30 \mathrm{~min}$; (b) fluorescence image from green channel of image (a); (c) the overlay of (a) and (b); (d) bright field image of RAW 264.7 cells stimulated with PMA $(1.5 \mu \mathrm{g} / \mathrm{mL})$ for 30 min and then incubated with $5.0 \mu \mathrm{M}$ probe 1 for 30 min; (e) fluorescence image from green channel of image (d); (f) the overlay of (d) and (e); (g) bright field image of RAW 264.7 cells stimulated with $1.5 \mu \mathrm{g} / \mathrm{mL}$ PMA for $30 \mathrm{~min}$, cultured with $5 \mu \mathrm{g} / \mathrm{mL}$ taurine, and then incubated with $5.0 \mu \mathrm{M}$ probe 1 for $30 \mathrm{~min}$; (h) fluorescence image from green channel of image (g); (i) the overlay of $(\mathrm{g})$ and $(\mathrm{h})$.

measure the cytotoxicity. We used the MTT method to determine the cytotoxicity of probe 1 and compound 2 to PC-12 cells and RAW 264.7 cells at different concentrations $(0,2,4,8$, and $16 \mu \mathrm{M})$ (Figure S3). As shown in Figure S3, when probe and compound 2 were present, the cell survival rate reaches more than $85 \%$, indicating that probe and compound 2 are almost nontoxic to PC-12 cells and RAW 264.7 cells.

In order to prove the practicality of probe in biological detection, we used fluorescent probe to perform laser confocal fluorescence imaging of $\mathrm{HOCl}$ in PC-12 cells and RAW 264.7 cells. PC-12 cells were seeded in a $35 \mathrm{~mm}$ laser confocal culture dish and cultured for 24 hours. After incubating for $30 \mathrm{~min}$ in a medium containing $5.0 \mu \mathrm{M}$ probe for fluorescence imaging, it was found that the green channel had almost no fluorescence (Figure 6(b)). At the same time, PC-12 cells were incubated with $5.0 \mu \mathrm{M}$ probe for $30 \mathrm{~min}$ and then incubated with $10 \mu \mathrm{M}$ $\mathrm{HOCl}$ for another $30 \mathrm{~min}$ and imaged. As shown in Figure 6(e), the fluorescence of the green channel was much stronger than that without HOCl. Next, we further assessed the capability of the probe 1 for imaging endogenous $\mathrm{HOCl}$. The trial was conducted in RAW 264.7 cells because the cells could generate high levels of $\mathrm{HOCl}$ after being stimulated by phorbol-12myristate-13-acetate (PMA) [51, 52]. The RAW 264.7 cells were 
hatched with $5.0 \mu \mathrm{M}$ probe, and weak fluorescence was observed in green channel (Figure $7(\mathrm{~b})$ ). When the cells were treated with $1.5 \mu \mathrm{g} / \mathrm{mL}$ PMA for $30 \mathrm{~min}$ and then hatched with $5.0 \mu \mathrm{M}$ probe for $30 \mathrm{~min}$, a remarkable fluorescence increase in RAW 264.7 cells was found (Figure 7(e)). However, after the cells stimulated with PMA were treated with taurine, which was an amino acid that could capture $\mathrm{HOCl}$ [52], and then incubated with $5.0 \mu \mathrm{M}$ probe for $30 \mathrm{~min}$, much weaker fluorescence was obtained (Figure $7(\mathrm{~h})$ ). Meanwhile, it also illustrated that the observed intracellular fluorescence enhancement was induced by the endogenous $\mathrm{HOCl}$ and no other ROS. These experimental results demonstrated that probe could be utilized for laser confocal imaging of exogenous and endogenous $\mathrm{HOCl}$ in living cells.

\section{Conclusions}

On the whole, we constructed and prepared a novel naphthalene-based fluorescent probe for the determination of hypochlorous acid. $\mathrm{N}, \mathrm{N}$-Dimethylthiocarbamate was chosen as the selective sensing unit for $\mathrm{HOCl}$. When $\mathrm{HOCl}$ was absent, the reported probe displayed weak fluorescence. In the presence of $\mathrm{HOCl}$, the probe exhibited green fluorescence. The probe had a short response time, a wide working $\mathrm{pH}$ range, and the high selectivity and specificity for hypochlorous acid. At the same time, the probe had good biocompatibility and is suitable for the detection of hypochlorous acid. In addition, confocal fluorescence imaging of living cells showed that the probe could be utilized to image exogenous and endogenous $\mathrm{HOCl}$ in living cells.

\section{Data Availability}

The data used to support the findings of this study are included within the article and Supplementary Materials.

\section{Conflicts of Interest}

The authors declare that they have no conflicts of interest.

\section{Acknowledgments}

The authors would like to thank the National Natural Science Foundation of China (21807027) and the Zhongjing Scholars Research Funding of Henan University of Chinese Medicine for their support.

\section{Supplementary Materials}

Figure S1. Absorption spectra of fluorescent probe $1(50 \mu \mathrm{M})$ and the reaction product of fluorescent probe $1(50 \mu \mathrm{M})$ with $\mathrm{HOCl}(200 \mu \mathrm{M})$. The solid line $(-)$ and dotted line (..) represent fluorescent probe 1 and the reaction product of fluorescent probe 1 with $\mathrm{HOCl}$, respectively. Figure S2. HRMS spectrum of the reaction mixture of probe 1 with $\mathrm{HOCl}$. Figure S3. MTT assay of PC-12 cells in the presence of different concentrations of probe 1 (A) and compound 2 (B) for $24 \mathrm{~h}$ at $37^{\circ} \mathrm{C}$, respectively; MTT assay of RAW 264.7 cells in the presence of different concentrations of compound 1 (C) and compound 2 (D) for $24 \mathrm{~h}$ at $37^{\circ} \mathrm{C}$, respectively.
Figure S4. ${ }^{1} \mathrm{H}$ NMR spectrum of compound 2 in DMSO- $d_{6}$. Figure S5. ${ }^{13} \mathrm{C}$ NMR spectrum of compound 2 in DMSO- $d_{6}$. Figure S6. MS spectrum of compound 2. Figure S7. ${ }^{1} \mathrm{H}$ NMR spectrum of compound 1 in $\mathrm{CDCl}_{3}$. Figure S8. ${ }^{13} \mathrm{C} \mathrm{NMR}$ spectrum of compound 1 in $\mathrm{CDCl}_{3}$. Figure $\mathrm{S} 9$. MS spectrum of compound 1. (Supplementary Materials)

\section{References}

[1] H. Pelicano, D. Carney, and P. Huang, "ROS stress in cancer cells and therapeutic implications," Drug Resistance Updates, vol. 7, no. 2, pp. 97-110, 2004.

[2] D. I. Pattison and M. J. Davies, "Evidence for rapid inter- and intramolecular chlorine transfer reactions of histamine and carnosine chloramines: implications for the prevention of hypochlorous-acid-mediated damage," Biochemistry, vol. 45, no. 26, pp. 8152-8162, 2006.

[3] J. E. Harrison and J. Schultz, "Studies on the chlorinating activity of myeloperoxidase," Journal of Biological Chemistry, vol. 251, no. 5, pp. 1371-1374, 1976.

[4] C. C. Winterbourn, "Myeloperoxidase as an effective inhibitor of hydroxyl radical production. Implications for the oxidative reactions of neutrophils," Journal of Clinical Investigation, vol. 78, no. 2, pp. 545-550, 1986.

[5] D. Lapenna and F. Cuccurullo, "Hypochlorous acid and its pharmacological antagonism: an update picture," General Pharmacology: The Vascular System, vol. 27, no. 7, pp. 1145-1147, 1996.

[6] M. J. Steinbeck, L. J. Nesti, P. F. Sharkey, and J. Parvizi, "Myeloperoxidase and chlorinated peptides in osteoarthritis: potential biomarkers of the disease," Journal of Orthopaedic Research, vol. 25, no. 9, pp. 1128-1135, 2007.

[7] A. Daugherty, J. L. Dunn, D. L. Rateri, and J. W. Heinecke, "Myeloperoxidase, a catalyst for lipoprotein oxidation, is expressed in human atherosclerotic lesions," Journal of Clinical Investigation, vol. 94, no. 1, pp. 437-444, 1994.

[8] E. Malle, T. Buch, and H. J. Grone, "Myeloperoxidase in kidney disease," Kidney International, vol. 64, no. 6, pp. 1956-1967, 2004.

[9] Y. W. Yap, M. Whiteman, and N. S. Cheung, "Chlorinative stress: an under appreciated mediator of neurodegeneration?" Cellular Signalling, vol. 19, no. 2, pp. 219-228, 2007.

[10] O. Ordeig, R. Mas, J. Gonzalo, F. J. Del Campo, F. J. Muñoz, and C. de Haro, "Continuous detection of hypochlorous acid/ hypochlorite for water quality monitoring and control," Electroanalysis, vol. 17, no. 18, pp. 1641-1648, 2005.

[11] T. E. Caldwell, K. L. Foster, T. Benter, S. Langer, J. C. Hemminger, and B. J. Finlayson-Pitts, "Characterization of $\mathrm{HOCl}$ using atmospheric pressure ionization mass spectrometry," The Journal of Physical Chemistry A, vol. 103, no. 41, pp. 8231-8238, 1999.

[12] T. Watanabe, T. Idehara, Y. Yoshimura, and H. Nakazawa, "Simultaneous determination of chlorine dioxide and hypochlorite in water by high-performance liquid chromatography," Journal of Chromatography A, vol. 796, no. 2, pp. 397-400, 1998.

[13] F. Ding, H. Wen, R. Zhuo et al., "A novel ratiometric and colorimetric chemosensor for highly sensitive, selective and ultrafast tracing of $\mathrm{HClO}$ in live cells, bacteria and zebrafish," Analytica Chimica Acta, vol. 1161, p. 338472, 2021.

[14] J. Ballesta Claver, M. C. Valencia Mirón, and L. F. CapitánVallvey, "Determination of hypochlorite in water using a chemiluminescent test strip," Analytica Chimica Acta, vol. 522, no. 2, pp. 267-273, 2004. 
[15] G.-J. Mao, Y.-Y. Wang, W.-P. Dong et al., “A lysosometargetable two-photon excited near-infrared fluorescent probe for visualizing hypochlorous acid-involved arthritis and its treatment," Spectrochimica Acta Part A: Molecular and Biomolecular Spectroscopy, vol. 249, p. 119326, 2021.

[16] C. Ma, G. Zhong, Y. Zhao, P. Zhang, Y. Fu, and B. Shen, "Recent development of synthetic probes for detection of hypochlorous acid/hypochlorite," Spectrochimica Acta Part A: Molecular and Biomolecular Spectroscopy, vol. 240, p. 118545, 2020.

[17] X. Chen, F. Wang, J. Y. Hyun et al., "Recent progress in the development of fluorescent, luminescent and colorimetric probes for detection of reactive oxygen and nitrogen species," Chemical Society Reviews, vol. 45, no. 10, pp. 2976-3016, 2016.

[18] X. Jiao, Y. Li, J. Niu, X. Xie, X. Wang, and B. Tang, "Smallmolecule fluorescent probes for imaging and detection of reactive oxygen, nitrogen, and sulfur species in biological systems," Analytical Chemistry, vol. 90, no. 1, pp. 533-555, 2018.

[19] Z.-N. Sun, F.-Q. Liu, Y. Chen, P. K. H. Tam, and D. Yang, "A highly specific BODIPY-based fluorescent probe for the detection of hypochlorous acid," Organic Letters, vol. 10, no. 11, pp. 2171-2174, 2008.

[20] C. Zhang, Q. Nie, I. Ismail, Z. Xi, and L. Yi, "A highly sensitive and selective fluorescent probe for fast sensing of endogenous $\mathrm{HClO}$ in living cells," Chemical Communications, vol. 54, no. 31, pp. 3835-3838, 2018.

[21] Q. Duan, P. Jia, Z. Zhuang et al., "Rational design of a hepatoma-specific fluorescent probe for $\mathrm{HOCl}$ and its bioimaging applications in living hepG2 cells," Analytical Chemistry, vol. 91, no. 3, pp. 2163-2168, 2019.

[22] C. Duan, M. Won, P. Verwilst et al., "In vivo imaging of endogenously produced $\mathrm{HClO}$ in zebrafish and mice using a bright, photostable ratiometric fluorescent probe," Analytical Chemistry, vol. 91, no. 6, pp. 4172-4178, 2019.

[23] Y. Lou, C. Wang, S. Chi, S. Li, Z. Mao, and Z. Liu, "Construction of a two-photon fluorescent probe for ratiometric imaging of hypochlorous acid in alcohol-induced liver injury," Chemical Communications, vol. 55, no. 86, pp. 12912-12915, 2019.

[24] X. Jiao, Y. Xiao, Y. Li et al., "Evaluating drug-induced liver injury and its remission via discrimination and imaging of $\mathrm{HClO}$ and $\mathrm{H} 2 \mathrm{~S}$ with a two-photon fluorescent probe," Analytical Chemistry, vol. 90, no. 12, pp. 7510-7516, 2018.

[25] J. Wang, D. Cheng, L. Zhu et al., "Engineering dithiobenzoic acid lactone-decorated Si-rhodamine as a highly selective near-infrared $\mathrm{HOCl}$ fluorescent probe for imaging drug-induced acute nephrotoxicity," Chemical Communications, vol. 55, no. 73, pp. 10916-10919, 2019.

[26] A. Zheng, H. Liu, C. Peng, X. Gao, K. Xu, and B. Tang, “A mitochondria-targeting near-infrared fluorescent probe for imaging hypochlorous acid in cells," Talanta, vol. 226, p. 122152, 2021.

[27] X. Jiao, C. Liu, Q. Wang et al., "Fluorescence probe for hypochlorous acid in water and its applications for highly lysosome-targetable live cell imaging," Analytica Chimica Acta, vol. 969, pp. 49-56, 2017.

[28] C. Liu, Z. Li, C. Yu et al., "Development of a concise rhodamine-formylhydrazine type fluorescent probe for highly specific and ultrasensitive tracing of basal $\mathrm{HOCl}$ in live cells and zebrafish," ACS Sensors, vol. 4, no. 8, pp. 2156-2163, 2019.

[29] X. Chen, X. Wang, S. Wang, W. Shi, K. Wang, and H. Ma, "A highly selective and sensitive fluorescence probe for the hypochlorite anion," Chemistry-A European Journal, vol. 14, no. 15, pp. 4719-4724, 2008.
[30] Y.-K. Yang, H. J. Cho, J. Lee, I. Shin, and J. Tae, "A rhodamine-hydroxamic acid-based fluorescent probe for hypochlorous acid and its applications to biological imagings," Organic Letters, vol. 11, no. 4, pp. 859-861, 2009.

[31] Z. Lou, P. Li, Q. Pan, and K. Han, "A reversible fluorescent probe for detecting hypochloric acid in living cells and animals: utilizing a novel strategy for effectively modulating the fluorescence of selenide and selenoxide," Chemical Communications, vol. 49, no. 24, pp. 2445-2447, 2013.

[32] X. Xie, T. Wu, X. Wang et al., "A two-photon fluorescent probe for ratiometric visualization of hypochlorous acid in live cells and animals based on a selenide oxidation/elimination tandem reaction," Chemical Communications, vol. 54, no. 84, pp. 11965-11968, 2018.

[33] M. Sun, H. Yu, H. Zhu et al., "Oxidative cleavage-based nearinfrared fluorescent probe for hypochlorous acid detection and myeloperoxidase activity evaluation," Analytical Chemistry, vol. 86, no. 1, pp. 671-677, 2014.

[34] Z. Zhen, J. Fan, G. Cheng, S. Ghazali, J. Du, and X. Peng, "Fluorescence completely separated ratiometric probe for $\mathrm{HClO}$ in lysosomes," Sensors and Actuators B: Chemical, vol. 246, pp. 293-299, 2017.

[35] B. Wang, F. Zhang, S. Wang, R. Yang, C. Chen, and W. Zhao, "Imaging endogenous $\mathrm{HClO}$ in atherosclerosis using a novel fast-response fluorescence probe," Chemical Communications, vol. 56, no. 17, pp. 2598-2601, 2020.

[36] D. Li, Y. Feng, J. Lin et al., "A mitochondria-targeted twophoton fluorescent probe for highly selective and rapid detection of hypochlorite and its bio-imaging in living cells," Sensors and Actuators B: Chemical, vol. 222, pp. 483-491, 2016.

[37] B. Guo, H. Nie, W. Yang, Y. Tian, J. Jing, and X. Zhang, "A highly sensitive and rapidly responding fluorescent probe with a large Stokes shift for imaging intracellular hypochlorite," Sensors and Actuators B: Chemical, vol. 236, pp. 459465, 2016.

[38] P. Xing, Z. Zhang, Y. Niu, Y. Qi, L. Dong, and C. Wang, "Water solubility is essential for fluorescent probes to image hypochlorous acid in live cells," Chemical Communications, vol. 54, no. 71, pp. 9889-9892, 2018.

[39] D. Shi, S. Chen, B. Dong et al., "Evaluation of HOCl-generating anticancer agents by an ultrasensitive dual-mode fluorescent probe," Chemical Science, vol. 10, no. 13, pp. 3715-3722, 2019.

[40] Q. Ma, C. Wang, G. Mao, M. Tian, J. Sun, and S. Feng, “An endoplasmic reticulum-targeting and ratiometric fluorescent probe for hypochlorous acid in living cells based on a 1,8naphthalimide derivative," New Journal of Chemistry, vol. 44, no. 42, pp. 18389-18398, 2020.

[41] Q. Ma, J. Xu, X. Zhang, L. Zhou, H. Liu, and J. Zhang, “A naphthalene-based two-photon fluorescent probe for selective and sensitive detection of thiophenols," Sensors and Actuators B: Chemical, vol. 229, pp. 434-440, 2016.

[42] Q. Ma, J. Xu, G. Mao et al., "A highly sensitive and selective fluorescent probe for nitroxyl based on a naphthalene derivative," Analytical Methods, vol. 11, no. 6, pp. 832-843, 2019.

[43] Q. Ma, X. Li, J. Zhang, X. Zhu, L. Zhou, and H. Liu, “A novel two-photon fluorescent probe for the selective detection of hydrogen peroxide based on a naphthalene derivative," $A n$ alytical Methods, vol. 9, no. 31, pp. 4558-4565, 2017.

[44] W. Zhang, X. Zhao, W. Gu et al., "A novel naphthalene-based fluorescent probe for highly selective detection of cysteine with a large Stokes shift and its application in bioimaging," 
New Journal of Chemistry, vol. 42, no. 22, pp. 18109-18116, 2018.

[45] C. Wang, J. Xu, Q. Ma et al., "A highly selective fluorescent probe for hydrogen polysulfides in living cells based on a naphthalene derivative," Spectrochimica Acta Part A: Molecular and Biomolecular Spectroscopy, vol. 227, p. 117579, 2020.

[46] J. Li, C. S. Lim, G. Kim, H. M. Kim, and J. Yoon, "Highly selective and sensitive two-photon fluorescence probe for endogenous peroxynitrite detection and its applications in living cells and tissues," Analytical Chemistry, vol. 89, no. 16, pp. 8496-8500, 2017.

[47] X. Wu, H. Wang, S. Yang, H. Tian, Y. Liu, and B. Sun, "Highly sensitive ratiometric fluorescent paper sensors for the detection of fluoride ions," ACS Omega, vol. 4, no. 3, pp. 4918-4926, 2019.

[48] Y. Shen, X. Zhang, Y. Zhang, H. Li, and Y. Chen, "An ICTmodulated strategy to construct colorimetric and ratiometric fluorescent sensor for mitochondria-targeted fluoride ion in cell living," Sensors and Actuators B: Chemical, vol. 258, pp. 544-549, 2018.

[49] Y. Bai, M.-X. Wu, Q.-J. Ma et al., "A FRET-based ratiometric fluorescent probe for highly selective detection of cysteine based on a coumarin-rhodol derivative," New Journal of Chemistry, vol. 43, no. 37, pp. 14763-14771, 2019.

[50] B. Zhu, L. Wu, M. Zhang et al., "A highly specific and ultrasensitive fluorescent probe for monitoring hypochlorous acid and its applications in live cells," Sensors and Actuators B: Chemical, vol. 267, pp. 589-596, 2018.

[51] B. Zhu, P. Li, W. Shu et al., "Highly specific and ultrasensitive two-photon fluorescence imaging of native $\mathrm{HOCl}$ in lysosomes and tissues based on thiocarbamate derivatives," $A n$ alytical Chemistry, vol. 88, no. 24, pp. 12532-12538, 2016.

[52] B. Wang, P. Li, F. Yu et al., "A reversible fluorescence probe based on Se-BODIPY for the redox cycle between $\mathrm{HClO}$ oxidative stress and H2S repair in living cells," Chemical Communications, vol. 49, no. 10, pp. 1014-1016, 2013. 